\title{
Meticulous Depiction and Genetic Mechanism of Unconformity Belt Structure
}

\author{
Zhipeng Lin ${ }^{1,2}$, Jingfu Shan ${ }^{1,2} \&$ Le Chen ${ }^{1,2}$ \\ ${ }^{1}$ School of Geosciences, Yangtze University, Caidian, Wuhan, China \\ ${ }^{2}$ Key Laboratory of Exploration Technologies for Oil and Gas Resources, MOE, Yangtze University, Wuhan, \\ China
}

First author: Zhipeng Lin, School of Geosciences, Yangtze University, Caidian, Wuhan, China. Tel: 86-136-9734-7719. E-mail: lzp19680201@foxmail.com

Correspondence: Jingfu Shan, School of Geosciences, Yangtze University, Caidian, Wuhan, China. Tel: 86-139-7210-2588. E-mail: shanjingfu2003@163.com

Received: December 10, 2016

doi:10.5539/esr.v6n2p19
Accepted: December 30, 2016 Online Published: February 24, 2017

URL: https://doi.org/10.5539/esr.v6n2p19

\begin{abstract}
Current research on unconformity belt mainly concentrates on the analysis and description of unconformity surface and contact relationship with overlying and underlying strata. Too much emphasis on the division of the "three-layer structure" of unconformity yields obvious disadvantages, i.e., that studies are not only insufficient in the authenticity of architecture but also in the characterization of the combination of the two- and three-dimensional perspectives. Thus, the analysis of genetic mechanism and meticulous depiction is ignored. Accordingly, by making full use of the outcrops and combining previous research findings, this study aims to provide a detailed description and analysis for the unconformity belt structure, and points out the non-uniqueness of the three-layer structure of the unconformity belt. Based on the theory of depositional process and according to the method and principle of the "point-line-surface", a comprehensive characterization method combined with a kind of "two-dimensional structure" and "three-dimensional structure" is proposed. A two-dimensional structure is a kind of surface structure, while the three-dimensional structure is a kind of body structure, Moreover, this study discusses the recognition significance of the visual unconformity line and visual unconformity surface with respect to the unconformity belt structure. According to the spatial allocation and geological significance of the unconformity belt, two types of models are established in order to depict the structure of unconformity belt better. Combined with the structural elements of the unconformity belt and complied from the viewpoint of the sedimentary environment, the formation mechanism of two-and three-dimensional structures is summarized.
\end{abstract}

Keywords: unconformity belt, unconformity belt structure, visual unconformity line, point-line-surface, three-layer structure

\section{Introduction}

Unconformity is an important geological phenomenon and a significant symbol of geological development (Fu, Xu, Han \& Ji, 2001; Farouk \& El-Sorogy, 2015; Gao \& Fan, 2015). The define for "unconformity" refers to a buried surface of erosion which may occur during stratigraphic successions (Mitchum, 1977; Miall, 1984; Winter \& Brink, 1991; Friedman, Sanders, \& Kopaska-Merkel, 1992; Gao \& Fan, 2015), and it is also a key to the definition of sequences in the geological record (Sattler, Immenhauser, Hillgartner, \& Esteban, 2005; Miall, 2016) and to the interpretation of tectonic subsidence (Ryu, Chang, \& Kim, 2005; Pinet, Lavoie, Dietrich, Hu, \& Keating, 2013). For a long term the focus derived from unconformity lies on the significance for sequence stratigraphy and palaeoenvironmental change. Eliot Blackwelder (1909) firstly discussed the relationship between the unconformities and what we would now call sequences by demonstrate the Phanerozoic record of North America. Furtherly, Andrew D. Miall (2015) systematicly provided an overall analysis of the nature of unconformities from the perspective of chronostratigraphic methods and reliable Global Time Scale. Researches for the identification and interpretation have revealed that unconformity has a vital importance for palaeoenvironmental and palaeogeographic reconstructions, sequence stratigraphy and petroleum reservoir assessments (Befus, 1994; Clari, Dela, \& Martire, 1995; Burchette, 1996; Sattler et al., 2005; Chow \& Wendte, 
2011; Nieto, Rodriguez-Tovar, Molina, Reolid, \& Ruiz-Ortiz, 2014).

However, few researches adequately pay attention to the meticulous structure within unconformity. Though the zone within unconformity is a good channel for oil and gas (Ziegler, 2000; Wu, Zou, Zha, \& Gao, 2012), and possibly a result of the activation of tectonic events (Qu et al., 2014; Zecchin, Praeg, Ceramicola, \& Muto, 2015), the migration and accumulation of oil and gas depends on the inner structure of unconformity (Fu, Duan, \& Meng, 2005; Wang, Cao, Wang, \& Song, 2006). Studies on the unconformity structure still fail to reach a common understanding. Through the research of carbonate rocks in the North Tarim (Tabei) uplift, Zhang Keyin (1996) initially proposed the mode of three-layer structure of unconformity surface: deposit layer, seepage flow layer and under flow layer, and discussed the controlling effect on oil and gas. By combining research on the unconformity surface, Fu et al. (2001) suggested that the unconformity could be divided from top to bottom into three parts: disintegration zone, leaching zone, hydrolysis zone. Based on the study of the Junggar basin, in an earlier stage, Wu et al. (2009) also divided the unconformity into three layers: rocks above the unconformity, weathered clay layer and semi-weathered clay layer on the unconformity surface. Later, he put forward the concept of "The structural body of unconformity" and divided it as follows: the upper layer, the middle layer and the lower layer. Moreover, through study of the Central Hebei Depression, Qu et al. (2013) proposed unconformity belt with the structure: water flooded layer, weathered clay layer and semi-weathered rock layer. The define of "unconformity belt", in a word, is the zone with a certain degree of independent structure around the unconformity, so it is not simply a surface nor a simple three-dimensional body, but rather the composite structure of a "body-surface" (Figure 3). So in order to depictict the structure easily, here adopts the "unconformity belt", which is more comprehensive than the word "unconformity".

In fact, the suggestion of unconformity structure itself is a fuzzy and abstract concept because unconformity is a product of geological events and various factors. It is not simply a single concept of spatial structural body, but a composite spatial structural body based on the perspective of process. Therefore, although many analyses of the unconformity structure aimed at a region are proceeding correctly, the lack of detailed classification and demonstration has become a fatal weakness. A more simple description of unconformity is essential. Accordingly, in order to describe the unconformity structure more comprehensively and truthfully, the authors provide a more specific lateral correlation and longitudinal analysis based on the different regions.

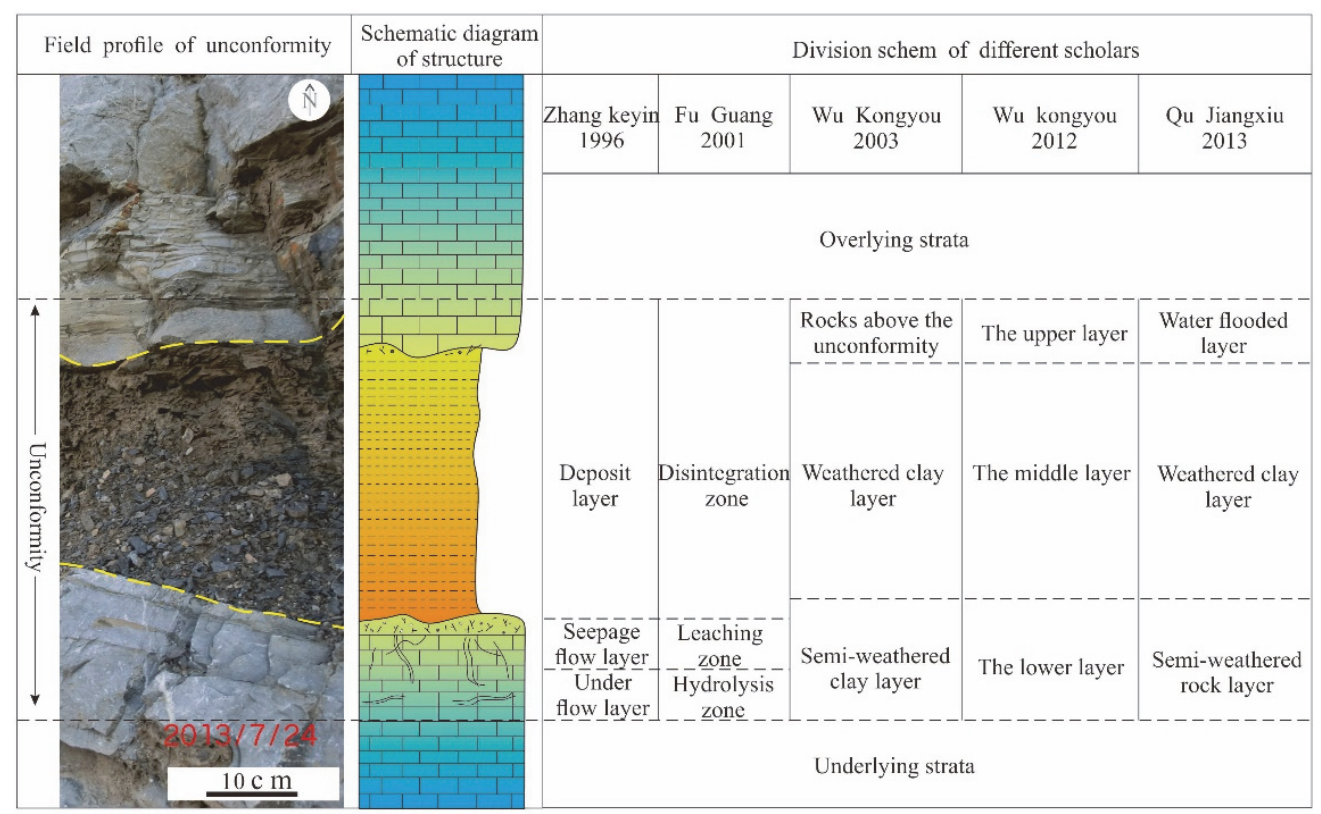

Figure 1. Comparison of Classification for Unconformity Belt Structure

\section{Geology Background}

Unconformity is a composite product generated from geological conditions of inharmonious time and space under a certain time scale and a certain space concept. Many scholars have pointed out that the unconformity has a vertical structure (Figure 1) (Zhang, 1996; Fu, 2001; Wu, 2012; Qu et al., 2013). It can be seen that the unconformity is not just a simple "two-dimensional surface" but more likely to be process of a "three dimensional body", which has been recognized by most researchers. According to this "spatial attribute", Wu et 
al. (2012) put forward the concept of structural body of unconformity. However, not all the characteristics of the space body can be seen in the field section, and not all unconformity has such a structure. In many cases, it also has the structure of a surface.

\subsection{Basic Types of Unconformity Belt}

It is vital to comprehend the type of unconformity belt in order to understand the analysis of structure, determination of the sedimentary environment and migration and accumulation of hydrocarbon. Many scholars at home and abroad have put forward the classification schemes from different angles (Table 1) (Gao, Peng, \& Li, 2013) but have not yet reached a unified understanding. Billings (1956), Yin (1978) and Lu (1980) classified the unconformity according to the geometric contact relationship of upper and lower strata, which was advantageous to the analysis of the change in formation occurrence. Vail (1977), Ai et al. (1996), Guo et al. (2006), Gao et al. (2013) and so on divided it from the angle of seismic reflection characteristics, which was conducive to the combination of sequence theory. Brown (1979), Wu et al. (1998), Qiu et al. (2002) and Yang (2006) classified the unconformity through the research of genetic mechanism, helping to further deepen the study of formation process and mechanism. Throughout the previous classification of unconformity, the geometric contact relationship between the upper and lower strata was the most studied. Discussion on the genetic mechanism is also limited in large sedimentary tectonics and there is a lack of discussion on the unconformity structure and formation process.

Table 1. Classification Scheme for the types ofunconformity belts

\begin{tabular}{|c|c|c|c|}
\hline Scholar & Year & Basis & Types \\
\hline Billings & 1956 & formation occurrence & angle unconformity, parallel unconformity \\
\hline Vail, etc. & 1977 & seismic reflection & erosion, toplap, onlap, downlap, top boundary concordance, bottom boundary \\
\hline Yin Zanxun & 1978 & formation occurrence & $\begin{array}{l}\text { angle unconformity, parallel unconformity, embedding unconformity, overlap } \\
\text { unconformity, intrusion unconformity }\end{array}$ \\
\hline Brown, etc & 1979 & genetic mechanism & erosion type, sedimentary type \\
\hline Lu Kezheng, etc & 1980 & formation occurrence & angle unconformity, parallel unconformity, nonconformity \\
\hline Ai Huaguo, etc & 1996 & seismic reflection & $\begin{array}{l}\text { fold unconformity, fault-fold unconformity } \\
\text { truncation unconformity, overlap unconformity, parallel unconformity }\end{array}$ \\
\hline Zhou Yaoqi, etc & 1997 & hiatus & erosion, high frequency section, underwater hard bottom, weathering surface \\
\hline Wu Yajun, etc & 1998 & genetic mechanism & structural unconformity, sedimentary unconformity, composite unconformity \\
\hline Qiu Yigang, etc & 2002 & genetic mechanism & $\begin{array}{l}\text { basal unconformity, episodic rifting unconformity, } \\
\text { local structural unconformity, local scour unconformity }\end{array}$ \\
\hline Guo Weihua, etc & 2006 & seismic reflection & $\begin{array}{l}\text { onlap-truncation, onlap-concordance type, } \\
\text { concordance-truncation type, concordance-concordance type }\end{array}$ \\
\hline Chang Botao & 2006 & tectonic stress & $\begin{array}{l}\text { overlap unconformity, offlap-truncation unconformity, parallel unconformity, } \\
\text { compound progressive and structural unconformity type }\end{array}$ \\
\hline Yang Yong & 2006 & genetic mechanism & $\begin{array}{l}\text { truncation unconformity, fold unconformity, diapir unconformity, } \\
\text { seismic unconformity, ancient karst unconformity, overlap unconformity, } \\
\text { parallel unconformity }\end{array}$ \\
\hline Gao Changhai, etc & 2013 & seismic reflection & $\begin{array}{l}\text { parallel-fold type, parallel-truncation type, parallel-parallel type, overlap-fold, } \\
\text { overlap-truncation type, overlap-parallel type }\end{array}$ \\
\hline
\end{tabular}

\subsection{Structural Elements of Unconformity Belt}

The analysis for unconformity belt structure first needs to determine how to describe and know what the structural elements are. For a long time, researches are mostly focused on geometric contact relationship between the upper and lower strata, but specific structure has not yet been systematically explained. Although some scholars have proposed that the variables of unconformity include spatial, time and geometric (Sloss, 1988; He, 2007), this kind of macro-scale variable cannot describe unconformity belt structure in detail or show characteristics. Therefore, it is necessary to conduct more further system studies.

The main problem is how to identify unconformity belt in practical work. As is shown in Figure 2, the usual method is to observe the occurrence of upper and lower layers from macro-scale. This usually makes it easy to identify the profile such as b, c, d, e in Figure 2. However, structures like a and f, where there is little difference in geometric shape between upper and lower strata, require further research. Although this method is reasonable 
and convenient, it has some uncertainty in the description of unconformity belt structure and lacks recognition basis and a descriptive method based on the feature of unconformity belt. While carefully observing the unconformity belt structure from micro-scale, it can be found that there is a relatively clear single interface in the structure of a, while $\mathrm{d}$, e, and $\mathrm{f}$ are relatively fuzzy; sometimes two adjacent interfaces are visible. The classification and comparison of this kind of phenomenon can be summarized from the microscopic level to figure out the main structural elements of unconformity belt (Figure 3).
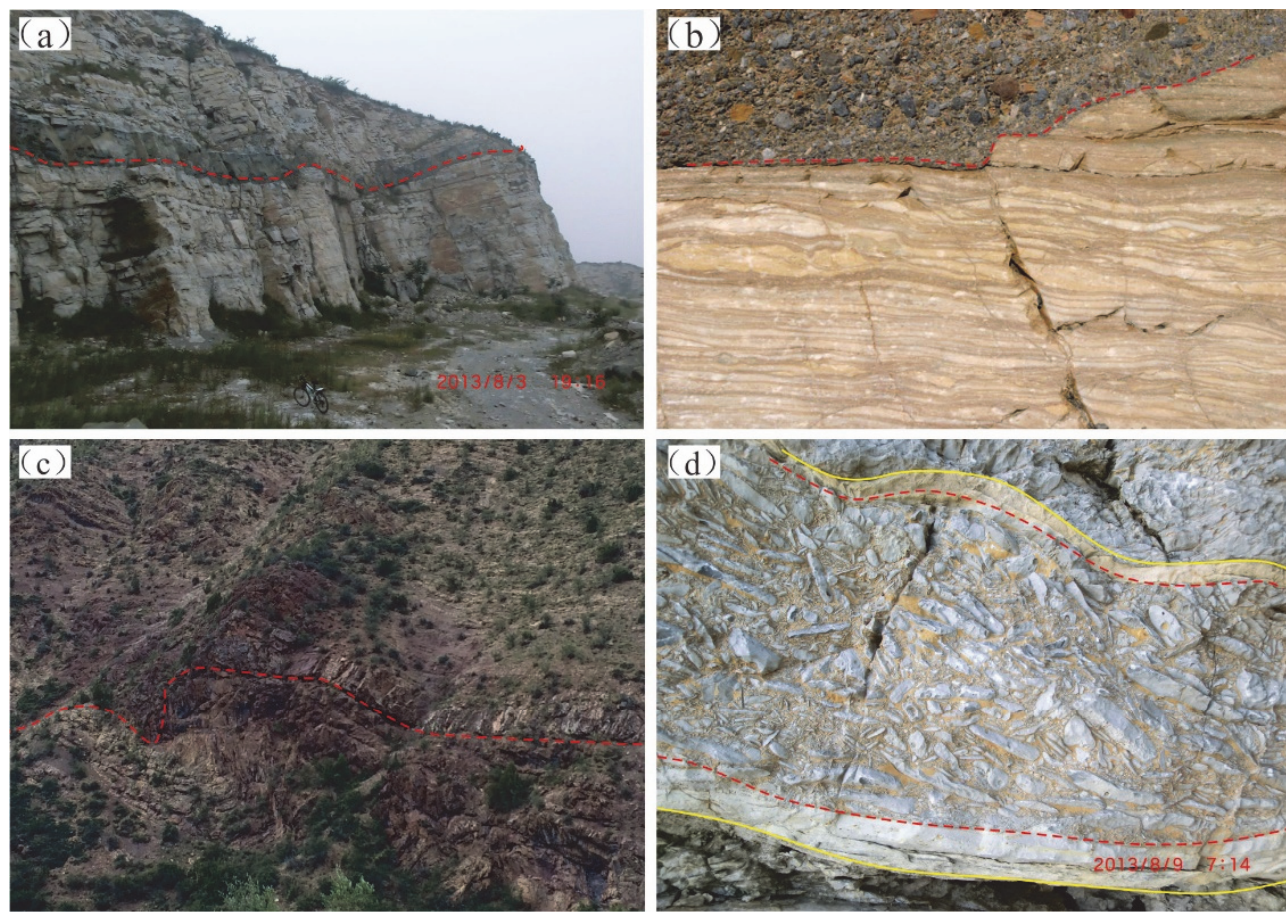

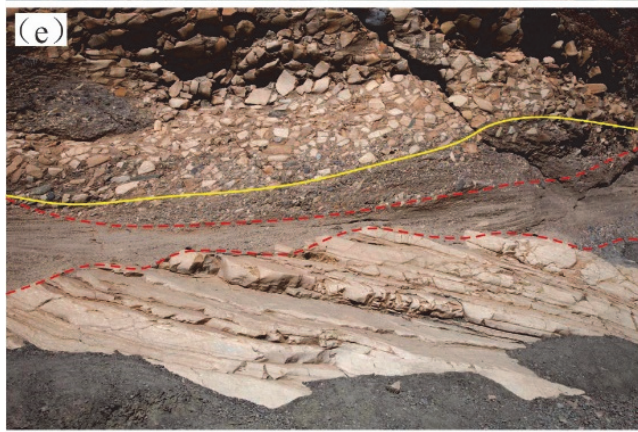

Key

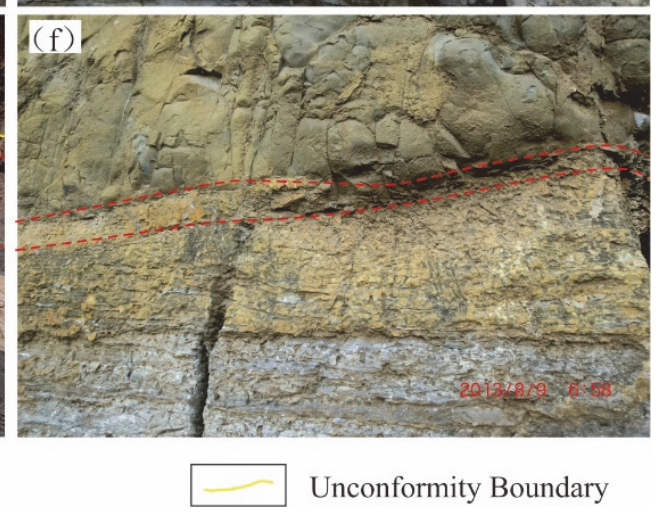

Figure 2. Structural profile of different unconformity belts in the outcrop: (a), (d), (f)Taken in Liu Jiang Basin, Qin Huangdao, China(2013.08); (c) Taken in Tibet, China (2015.6); (b) (2006.05), (e)(2006.05) Taken in Death Valley, California, USA, photos by Bryant Miller Marli

\subsection{Visual Unconformity Line and Visual Unconformity Surface}

The visual unconformity line is an uncoordinated contact line that is visible to the naked eye between two sets of strata in a field profile observation, and the corresponding extension surface between the upper and lower strata is the unconformity surface (Figure 3). This macroscopic method determines the uncertainty of the visual unconformity line, but because it is objective and easy to observe, it has important significance for the identification of unconformity belt. It should be noted that the visual unconformity line is not necessarily the boundary line of unconformity belt, but rather the macro-visible line, and not necessarily the only one. The red line of $a, b$, and $c$ in Figure 2 is a combination of visual unconformity line and unconformity belt itself; they coincide with each other. However, there are two visual unconformity lines in Figure 2d, e, and f. The upper red 
line is upper visual unconformity line, while the lower one is lower visual unconformity line. None of them is the unconformity boundary, but rather the favorable identification line of the unconformity belt. In Figure 2e, the lower visual unconformity line coincides with the lower unconformity boundary, and the upper visual unconformity line is locate below the upper unconformity boundary. In Figure $2 \mathrm{f}$, two visual unconformity lines and the unconformity boundary coincide with each other.

\subsection{Unconformity Boundary}

It can be seen from the field outcrop that there are two kinds of unconformity boundary conditions. One is shown in Figure 2a, b, and c: the unconformity itself is a boundary line and there is no thickness spatially. The other is similar to Figure 2d, e, and f: the unconformity belt has a certain thickness, corresponding with two unconformity boundaries: the upper unconformity boundary and lower unconformity boundary (Figure 3 ). The upper unconformity boundary is the stable contact position with the underlying unconformity belt, where the overlying strata do not play a role in the weathering and leaching of unconformity belt. The lower unconformity boundary is the stable contact position with the overlying unconformity belt, where the underlying strata do not play a role in the weathering and leaching of the unconformity belt. Between the upper unconformity boundary and lower unconformity boundary is the complete unconformity belt structure. Then, the relationship between the unconformity boundary and visual unconformity line can be understood from this conception (Figure 4).

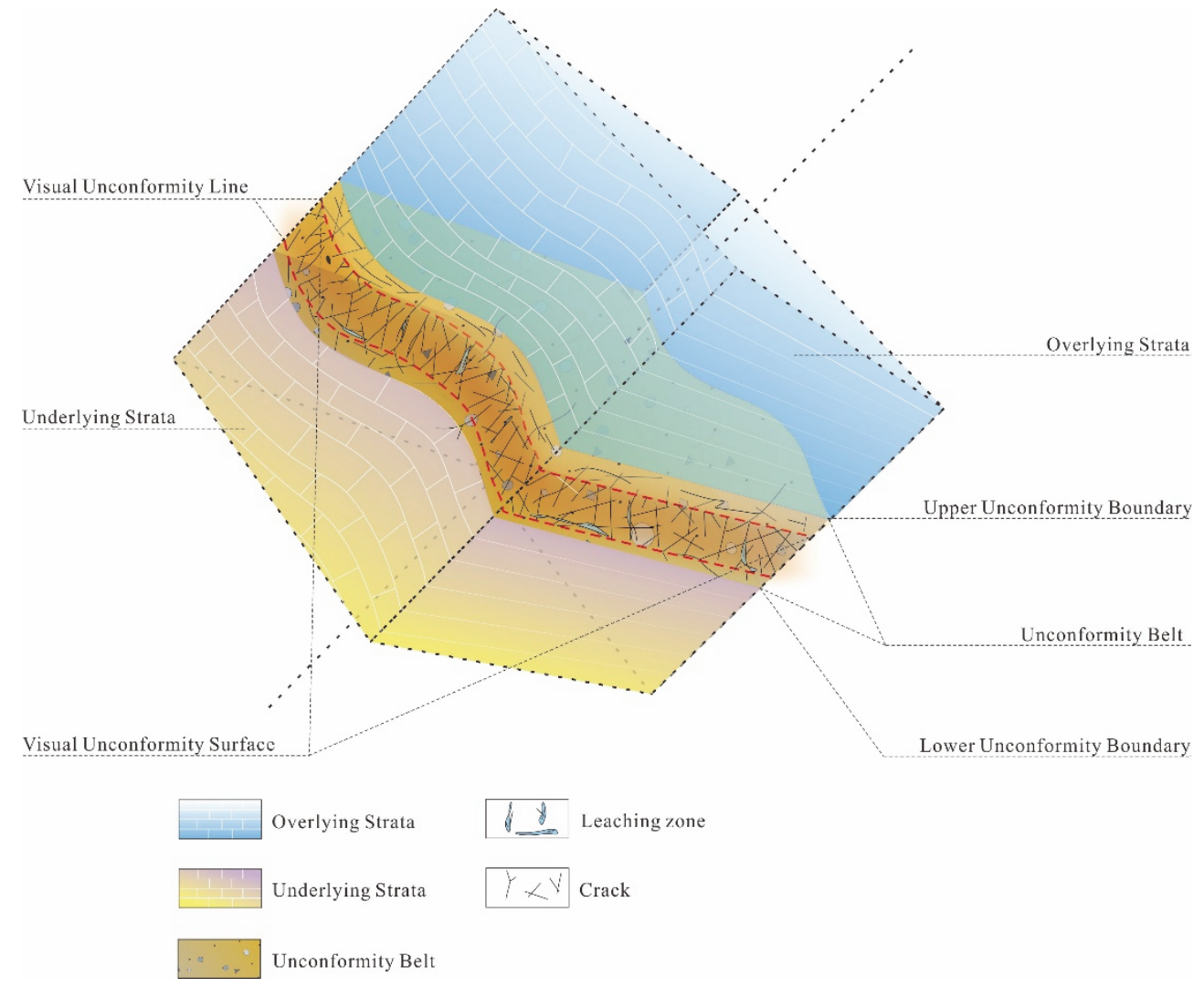

Figure 3. Structural element of unconformity belt 


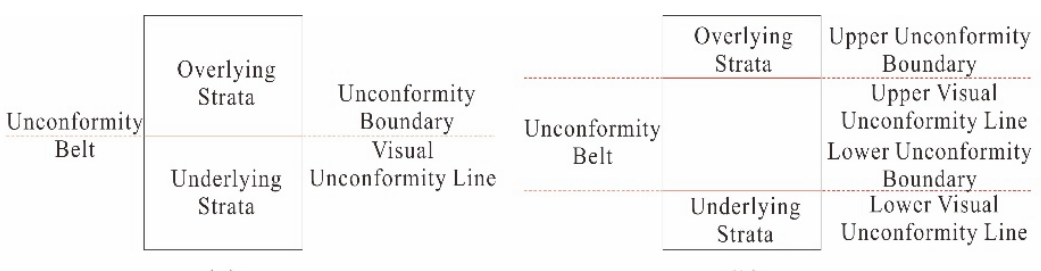

(a)

(b)

\begin{tabular}{|c|c|c|c|c|c|c|c|c|}
\hline & $\begin{array}{c}\text { Overlying } \\
\text { Strata }\end{array}$ & $\begin{array}{c}\text { Upper Unconformity } \\
\text { Boundary }\end{array}$ & & $\begin{array}{l}\text { Overlying } \\
\text { Strata }\end{array}$ & $\begin{array}{c}\text { Upper Unconformity } \\
\text { Boundary }\end{array}$ & & $\begin{array}{l}\text { Overlying } \\
\text { Strata }\end{array}$ & $\begin{array}{c}\text { Upper Unconformity } \\
\text { Boundary }\end{array}$ \\
\hline \multirow{6}{*}{$\begin{array}{l}\text { Unconformity } \\
\text { Belt }\end{array}$} & & Upper Visual & \multirow{4}{*}{$\begin{array}{c}\text { Unconformity } \\
\text { Belt }\end{array}$} & & Upper Visual & \multirow{4}{*}{$\begin{array}{c}\text { Unconformity } \\
\text { Belt }\end{array}$} & & Upper Visual \\
\hline & & Unconformity Line & & & Unconformity Line & & & Unconformity Line \\
\hline & & Lower Unconformity & & & Lower Visual & & & Lower Visual \\
\hline & & & & & Unconformity Line & & & Unconformity Line \\
\hline & $\begin{array}{c}\text { Underlying } \\
\text { Strata }\end{array}$ & \multirow[t]{2}{*}{$\begin{array}{c}\text { Lower Visual } \\
\text { Unconformity Line }\end{array}$} & & $\begin{array}{c}\text { Underlying } \\
\text { Strata }\end{array}$ & $\begin{array}{c}\text { Lower Unconformity } \\
\text { Boundary }\end{array}$ & & $\begin{array}{c}\text { Underlying } \\
\text { Strata }\end{array}$ & \multirow[t]{2}{*}{$\begin{array}{c}\text { Lower Unconformity } \\
\text { Boundary }\end{array}$} \\
\hline & (c) & & \multicolumn{3}{|c|}{ (d) } & \multicolumn{2}{|r|}{ (e) } & \\
\hline
\end{tabular}

Figure 4. The relationship between the unconformity boundary and visual unconformity Line: (a) The unconformity boundary and visual unconformity line coincide, corresponding with the unconformity belt structure, which can be refered to the photos of the figure $2 a, b$ and c; (b) The upper unconformity boundary and upper visual unconformity line coincide while the lower unconformity boundary and lower visual unconformity

line coincide, and between them is the unconformity belt structure, which can be refered to the photos of the figure 2f; (c) The upper unconformity boundary is on top of the upper visual unconformity line while the lower unconformity boundary and lower visual unconformity line coincide, and between the upper and lower unconformity boundary is the unconformity belt structure, which can be refered to the photos of the figure 2e; (d)

The upper unconformity boundary and upper visual unconformity line coincide while the lower unconformity

boundary is on bottom of the lower visual unconformity line; between the upper and lower unconformity boundary is the unconformity belt structure; (e) The upper unconformity boundary is on top of the upper visual unconformity line while the lower unconformity boundary is on bottom of the lower visual unconformity line, and between the upper and lower unconformity boundary is the unconformity belt structure, which can be refered to the photos of the figure $2 \mathrm{~d}$

\subsection{Vertical Thickness}

Some of the unconformity belt can only be observed as one unconformity interface in the field vertical profile, corresponding to the visual unconformity line, as shown in Figure 2a, b, and c, where it can be understood that the vertical thickness is 0 . However, two visual unconformity lines can be observed and the two corresponding unconformity boundaries can be identified. Between the upper and lower unconformity boundary is the unconformity belt structure, and the corresponding vertical distance is the vertical thickness, as shown in Figure $2 \mathrm{~d}$, e, and $\mathrm{f}$, which all have a certain vertical thickness. There is still no fixed standard for the vertical thickness of unconformity belt, which is related to the genetic mechanism. Different mechanisms can lead to different thicknesses. When the unconformity performs as a single line, the thickness is 0 . Earlier studies in the North Tarim uplift showed that the thickness of the structure layer ranged between 2 127 meters (Zhang, 1996). Research in Zhunggar Basin indicated that the thickness ranged between 14 174 meters (He, 2007). The study of the unconformity structure layer in Tarim Basin revealed that the thickness was in the range of 16.3 179 meters ( $\mathrm{Li} \& \mathrm{Ai}, 2006$ ). It is thus clear that the thickness of the unconformity belt structure varies considerably, which is closely related to the intensity of weathering, erosion, groundwater activity, tectonic activity and the paleoclimatic condition.

\subsection{Rock Types and Contact Relationship of the Upper and Lower Strata}

The rock types and contact relationship between the upper and lower strata are important factors for controlling the structure of unconformity belt. Various lithological association forms diverse structural features of unconformity belt. He (2007) divided the unconformity belt into 13 lithological combination patterns through the study in Zhunggar Basin. However, further discussion is required on the influence of different rock types. The contact relationship between is the geometric representation of the strata on both sides of unconformity belt. Many scholars have set this as the basis for division of the unconformity belt (Billings, 1972; Lu, 1980; Yin, 1978), which helps to further promote research on unconformity. Nevertheless, with the needs of developing fine reservoir characterization, the supporting structure of unconformity belt should not only be precise but also demonstrated from the genetic mechanism perspective. 


\section{Samples and Methods of Unconformity Belt Structure}

The unconformity belt structure has commonly developed three layered structural characteristics according to the research of Zhang (1996). However, such a model of structure layer established on this basis cannot cover all types of unconformity belts. It is just one kind of expression form and has not really covered the unconformity belt with structural characteristics. Not all of the unconformity is a three-layer structure or even a layered structure. According to the principle of realism, combined with the field outcrop and other first-hand materials of the previous research results, the establishment of classification criteria and the recognition principle of unconformity belt structure is attempted here.

\subsection{Two-Dimensional Unconformity Belt}

\subsubsection{Two-Dimensional Structure of Unconformity Belt}

There is less research on the two-dimensional structure of unconformity belt because the importance has not been widely recognized. The formation principles are numerous and varied, and it is helpful to analyze its development for understanding and grasping the geological events that occurred within a certain period. This not only has research significance for petroleum migration and accumulation but also provides important direction for the development and evolution of life activities and historical changes of geological activities.

If the strata under unconformity belt have not uplifted sufficiently to undergo weathering and denudation, they may receive new deposition due to a sudden geological event. Alternatively, uplifting occurred but was covered with new source without undergoing extensive subaerial weathering and alteration. Even if it was exposed due to geological events such as river erosion, which subjected the strata to weathering, leaching and subsequent erosion, it still creates the false appearance that upper strata make direct contact with lower strata, which is not subjected to weathering and denudation. In this way, the two-dimensional structure is formed, without weathered clay layer between unconformity zone or leaching-crushing zone beneath the surface and weathering-erosion zone above. There is only one visual unconformity line, on behalf of the two-dimensional interface, which is formed between the strata above and under the unconformity belt.

\subsubsection{Model of Two-Dimensional Structure}

Based on the characteristics of field profile and structural elements, a model of the two-dimensional structure was established (Figure 5). It can be seen through the structure coordinate direction graph that it has lateral attributes and planar extension attributes, which determine the characteristics of surface structure. From the section graph and the line structure graph, it can be seen that the performance in the vertical direction is a visual unconformity line without thickness. The manifestation in space seen from the stereoscopic structure graph is a visual unconformity surface coinciding with the structure.

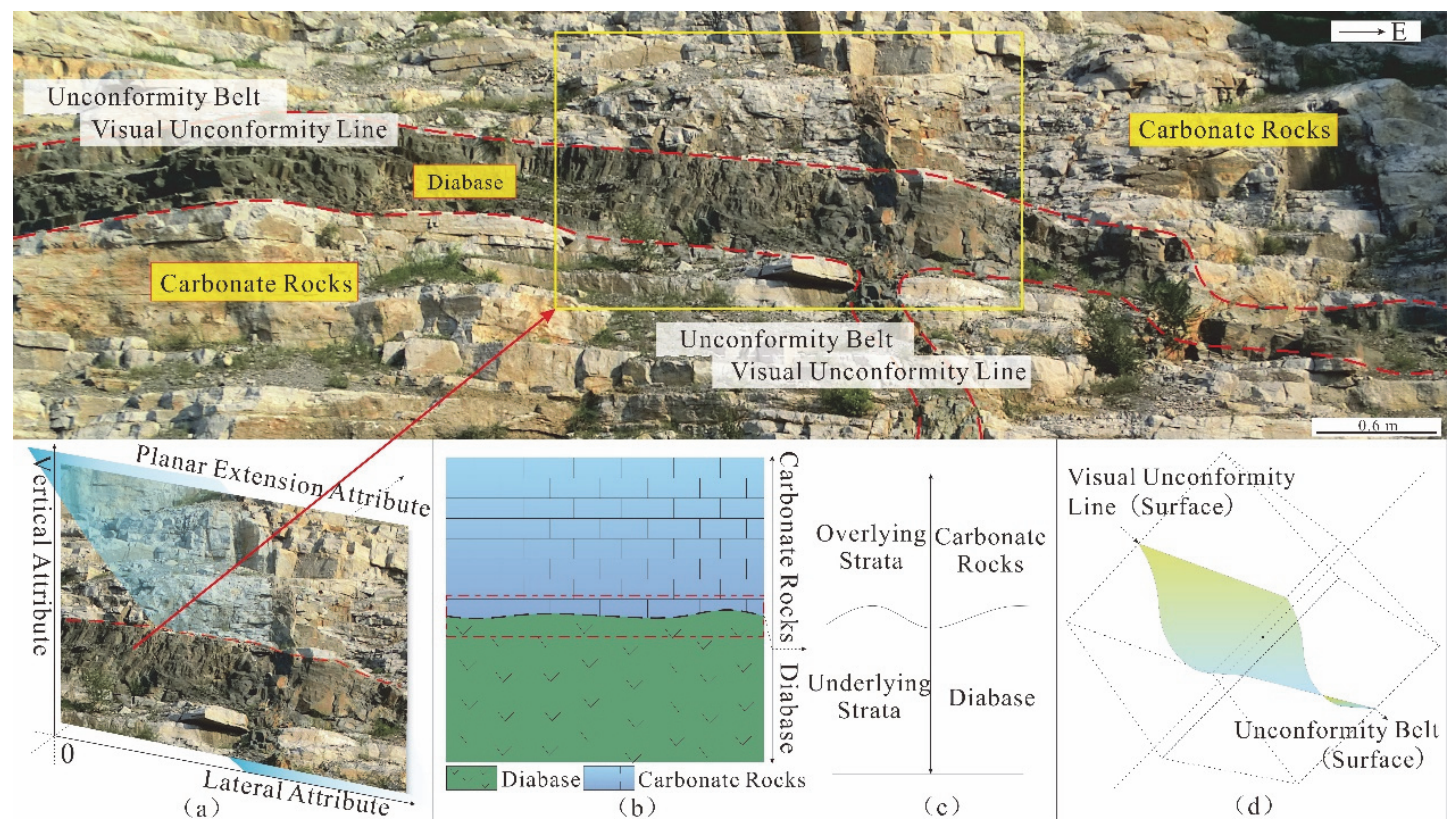

Figure 5. Model of two-dimensional structure of unconformity belt (taken in Liu Jiang Basin, 2013.08): (a)

Structure coordinate direction graph of unconformity belt; (b) Section graph of unconformity belt; (c) Line structure graph of unconformity belt; (d) Stereoscopic structure graph of unconformity belt 


\subsubsection{Study on Two-Dimensional Structure of Unconformity Belt Based on Field Outcrops}

The formation of a two-dimensional structure depends on an essential element and two key factors; the essential element is the sedimentary environment, while the key factors are sediment supply and tectonic setting. The sedimentary environment directly determines the formation and structure properties of unconformity belt, affecting the sediment types of unconformity belt. The quantity and time of source supplied directly affect the distribution range of the two-dimensional structure of the strata above the unconformity belt and the reservoir physical property of the strata. As an important adjustment role, the tectonic background directly impacts the unconformity type and development scale (Figure 6).

A clear understanding of the two-dimensional structure of unconformity belt can be determined based on Figure 6. The profile in Figure 6A is from the Liu Jiang Basin, Qinhuangdao City, Hebei Province, China. It can be clearly seen that the carbonate rocks formed in the Ordovician period were invaded by a set of diabase dykes, which constitute the two-dimensional structure with the upper and lower carbonate rocks. The spatial reflection is a two-dimensional surface, and here there are two surfaces. One is on the bottom of the diabase, contacting with the carbonate below. The other is on the top of the diabase, contacting with the carbonate above. The two unconformity surfaces have obvious characteristics, with no layered structure, weathering clay layer growth or characteristic of the upper and low layer of the structural body. To summarize, the visual unconformity line and unconformity belt coincide with each other.

The profile in Figure 6B is from Song $\mathrm{Zi}$, Liu Jiachang, China, which exhibits a typical river erosion surface. The carboniferous sandstone in the upper He Zhou Formation and the carbonate rocks in the lower part constitute the two-dimensional structure. It can be seen there is no hierarchical structure in the interface or weathered clay layer. The upper layer has no sandstone, basal conglomerate or water-inlet sandstone, while the lower layer has no weathering-leaching zone or dissolution-fracture zone. There is only one visual unconformity line without thickness, corresponding to the unconformity belt structure.

The profile in Figure 6C is a section from central Utah, USA. The upper Pleistocene sand-conglomerate covers the red sandstone of the lower Triassic strata, constituting the two-dimensional structure. The upper unconformity belt is a mixed gravel bed arranged disorderly that does not form part of the three-layer structure. The lower part is red sandstone, without layered structure, and the visual unconformity line and unconformity belt coincide with each other.

The profile in Figure 6D is based in Colorado, USA. The Precambrian granite at the bottom and the Cambrian sandstone on the top constitutes the two-dimensional structure; the overlying sandstone directly covers the lower granite, without layered structure, and the unconformity belt and visual unconformity lines coincide. 


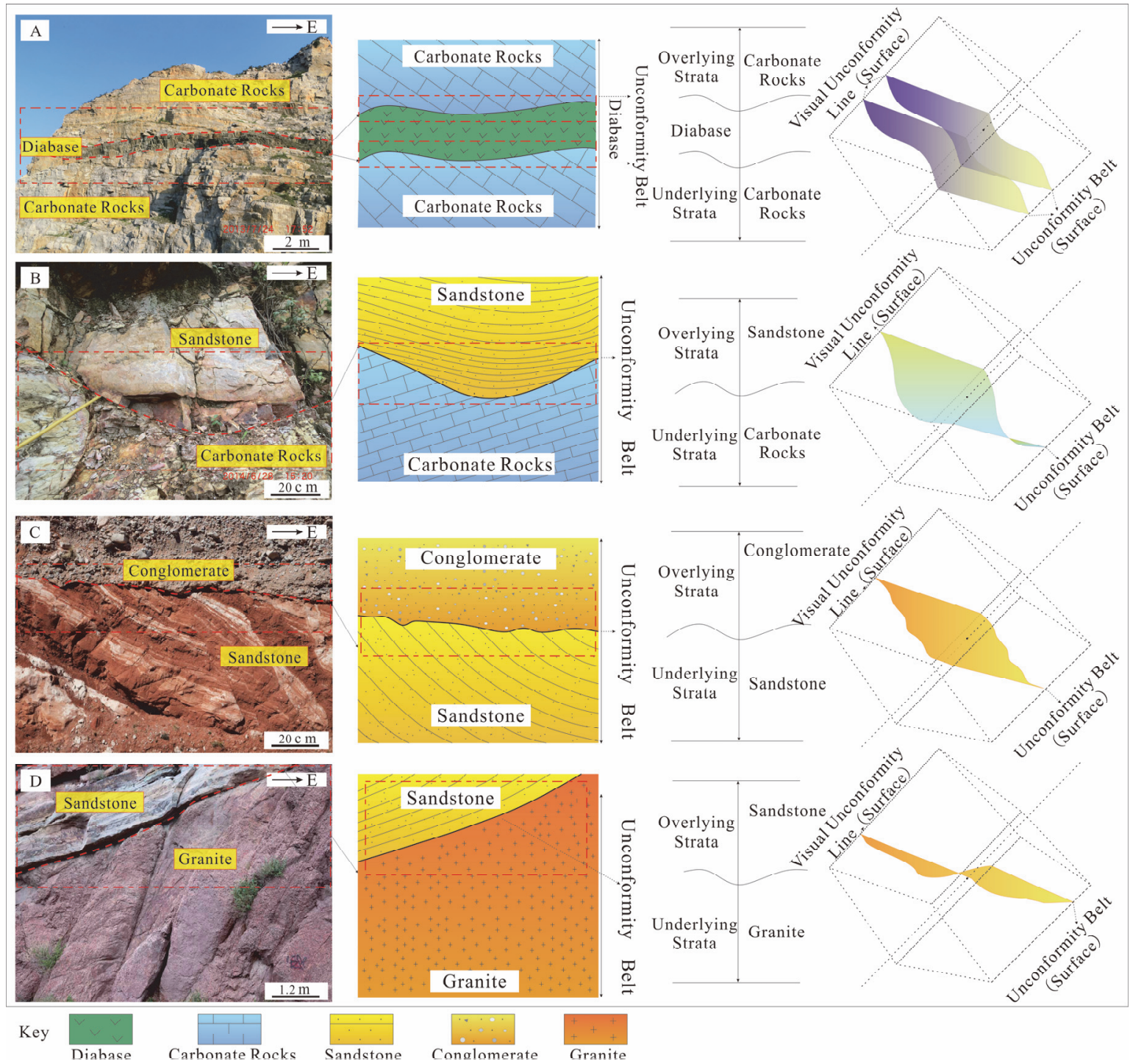

Figure 6. Analysis Graph of two-dimensional structure of unconformity belt in different outcrops: A taken in Liu Jiang Basin, Qin Huangdao, China, 2013.08; B taken in Liu Jiachang, China, 2014.06; C taken in Utah, USA, 2009.03 (photos by Bryant Miller Marli); D taken in Colorado, USA, 2011.07 (photos by Bryant Miller Marli)

The structures above, combined with the model of two-dimensional structure can be summarized as follows:

1) From the perspective of formation mechanism, the formed underlying strata of unconformity belt did not exhibit visual weathering and denudation. The formation process of the overlying strata indicates a certain degree of erosion of the underlying strata. For instance, Figure 6A belongs to magmatic intrusion and Figure 6B and $\mathrm{C}$ are scouring effects. Figure $6 \mathrm{D}$ remains to be studied with sand body genesis and is not discussed here. It can be seen that the formation mechanism influences the unconformity structure.

2) From the perspective of formation position, the two-dimensional structure is mainly formed in the inside stratum and the fluid interface of the flowing medium, with an invasion attribute or strong erosion property.

3) For the vertical characteristics of unconformity belt, there is no layered structure or weathered clay layer. The upper layer has no sandstone or basal conglomerate and no water-inlet sandstone; the lower layer has no weathering and leaching zone or dissolution-fracture zone. Further, the vertical thickness is 0 , and only the upper and lower layer of the unconformity belt can be observed.

4) For the shape of unconformity belt, only a clear contact line between the upper and lower layer is intuitively visible, that is, the visual unconformity line, which coincides with the unconformity boundary, representing the entire vertical structure. 


\subsection{Three-Dimensional Unconformity Belt}

\subsubsection{Three-Dimensional Structure of Unconformity Belt}

Petroleum geologists usually pay more attention to this structure because it is an important mineralizing channel and location. In addition, it plays an important role in the migration and accumulation of oil and gas.

If underlying strata uplifts the ground, lower strata can undergo weathering and denudation with various physical, chemical and biological effects, forming various weathering-fracture zones, weathering denudation pores and vadose zones. After a certain period of time, due to particular geological events, a new source supply originates; the overlying strata begins to deposit on the lower strata subjected to relatively long-term weathering and denudation in a certain geological period, and gradually undergos sedimentary compaction. In late geological history period, the diagenesis would be completed, so that a "three-dimensional" nature of the unconformity belt is formed.

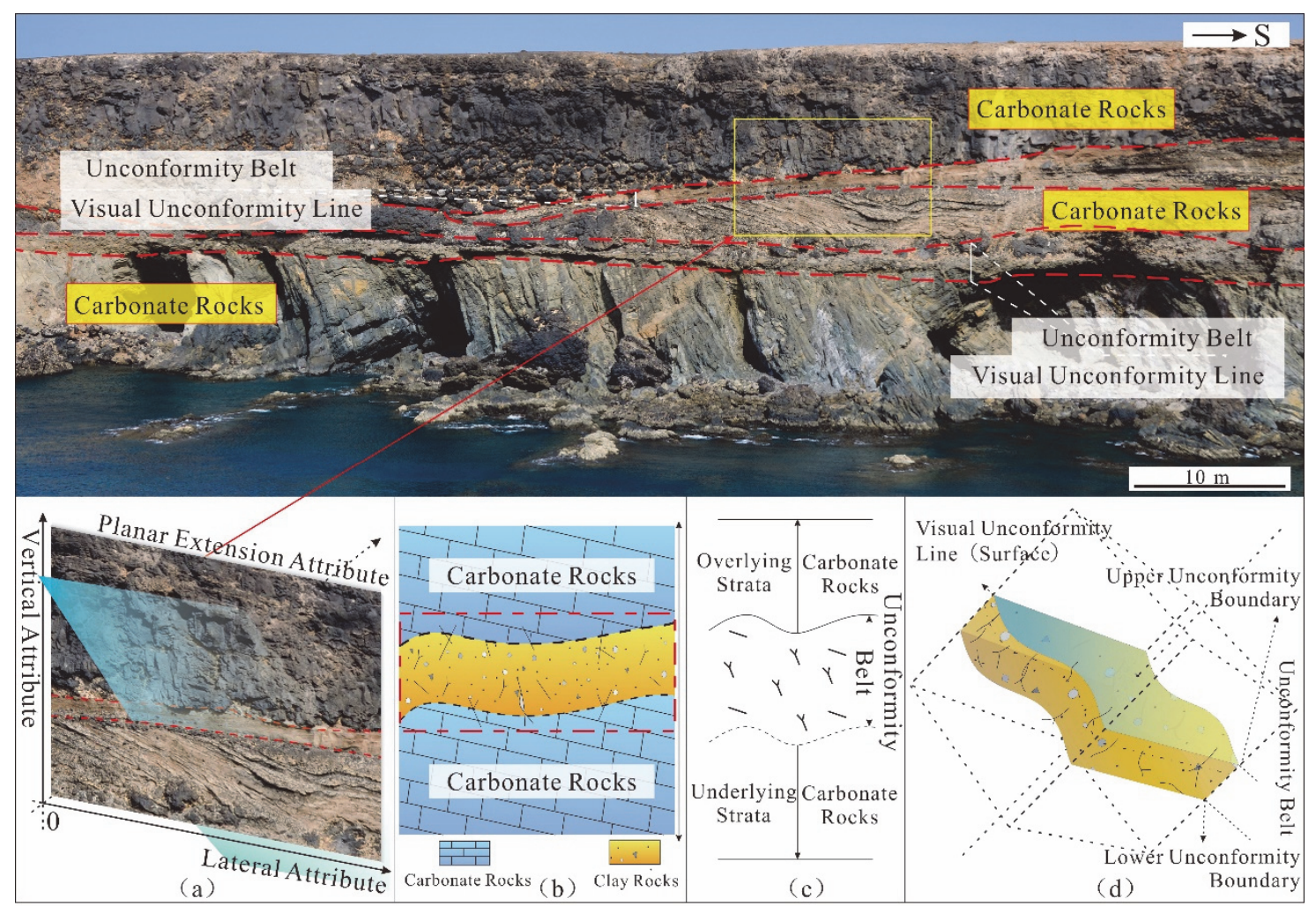

Figure 7. Model of three-dimensional structure of unconformity belt (taken in Spain, Canarias, Ajuy, 2012.01, from Xihuashe): (a) Structure coordinate direction graph of unconformity belt; (b) Section graph of unconformity belt; (c) Line structure graph of unconformity belt; (d) Stereoscopic structure graph of unconformity belt 


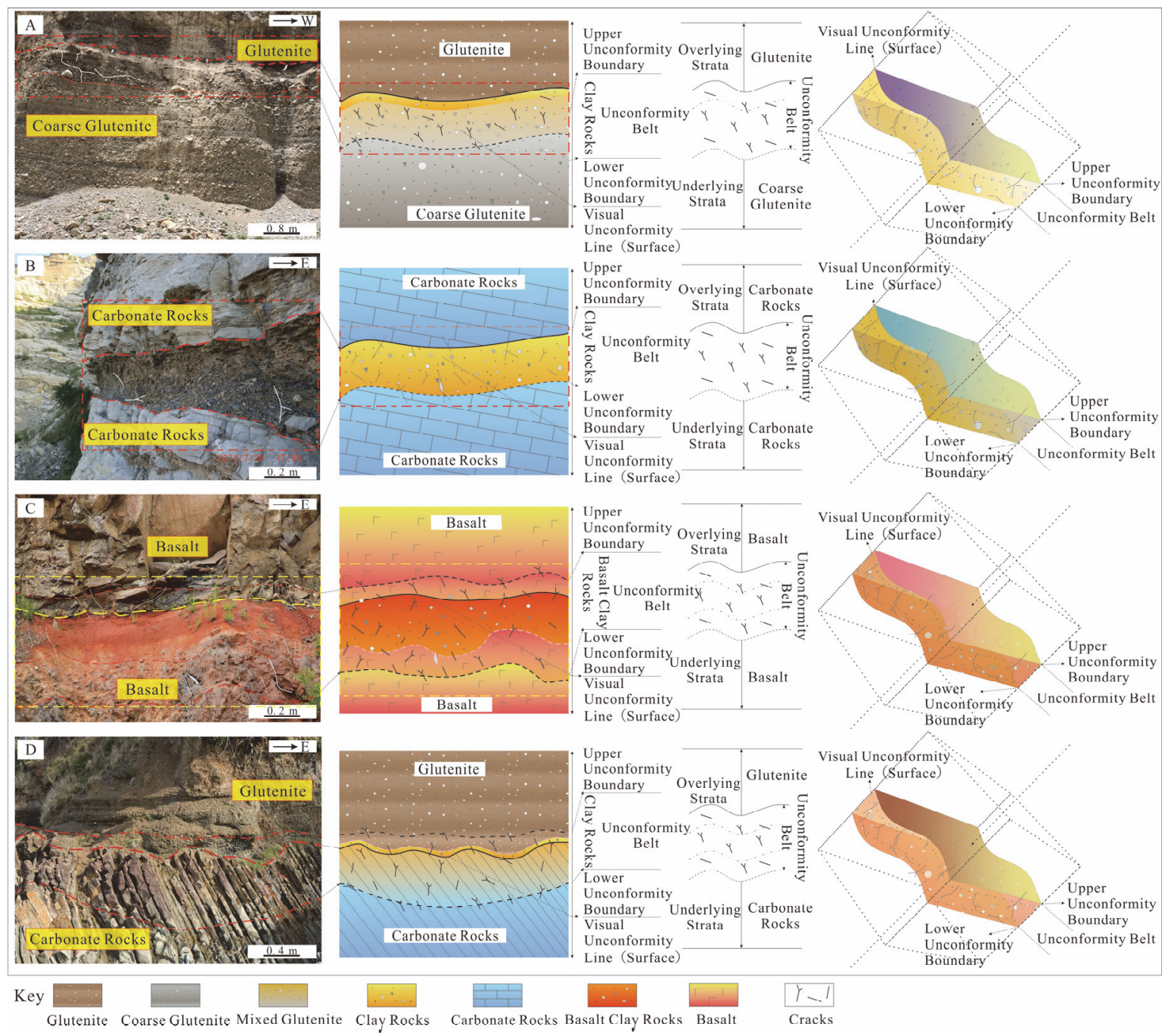

Figure 8. Analysis graph of three-dimensional structure of unconformity belt in different outcrops: A Taken in Tibet, China, 2015.07; B Taken in Liujiang Basin, Qin Huangdao, China, 2013.08; C Taken in Oregon, USA, 2010.06 (photos by Bryant Miller Marli); D Taken in Washington State, USA, 2007.03 (photos by Bryant Miller Marli)

\subsubsection{Model of Three-Dimensional Structure}

In common with the analysis method of two-dimensional structure, the model of three-dimensional structure is established (Figure 7). The difference is that while using the point - line - surface method and principle for analysis, the time scales and thickness need to be considered at the same time. The three-dimensional structure does not represent three-layer structure, and vertical thickness is the point. In fact, it can be seen that some unconformity belt structures do not have the bottom gravel stratum development, but rather a part of upper strata, some have no weathered clay layer, just some cracks or pores around the structure. The situation has no significance for division of three-layer structure.

This structure has two approximately parallel visual unconformity lines. Based on the structure coordinate direction graph, the structure has three attributes of lateral, vertical and planar extension, which determine its characteristic of body structure. In the line structure graph, it can be seen clearly that the belt has a width controlled by two visual unconformity lines; the upper layer of the belt is the overlying strata, and the lower layer is the underlying strata. From the stereoscopic structure graph of unconformity belt, this belt is a structural body of space; the upper of the body is the overlying strata, the lower is the underlying strata. This spatial structural body is unconformity belt itself, with stratum property. It can be seen that within this belt, there are uncoordinated changes with upper and lower strata, such as weathering, fracture, corrosion, percolation, 
deformation and so on, showing the characteristics of the three-dimensional structure. Combined with the actual profile, the characteristics of the three-dimensional structure can be directly observed through the pattern diagram.

\subsubsection{Study on Three-Dimensional Structure of Unconformity Belt Based on Field Outcrops}

Similar to the two-dimensional structure, the three-dimensional structure also depends on an essential element and two key factors. The essential element is sedimentary environment, which directly determines the formation process and structure properties. This is same with the two-dimensional structure. However, the key factors do not include tectonic setting but contain the weathering and erosion conditions and sediment supply. The weathering conditions should be emphasized here, because only after the underlying strata are exposed to weathering, denudation and leaching and under the condition that the source supply is sufficient, a vertical stratification structure has potential to form, in addition to the two-dimensional surface (Figure 8).

A certain understanding of the three-dimensional structure can be acquired from the section in Figure 8. A three-dimensional structure does not mean a three layer structure, and it does not indicate a good hierarchical structure. Picture A is the Quaternary field profile of Baxoi County in Tibet, China. It can be clearly seen that an apparent visual unconformity lies between the underlying coarse glutenite and overlying sandy conglomerate. Unlike the two-dimensional structure, the upper layer of the structure is the normal glutenite deposition while the lower layer develops a weathered clay layer. Below the weathered clay layer is $1 \sim 3$ meters of sandy conglomerate, which is slightly different from the underlying sandy conglomerate. This has been subjected to relatively strong erosion, and a large number of pores and cracks are visible to the naked eye. This was termed mixed sand conglomerate to distinguish it from the underlying coarse gravel rock. This layer of mixed sand conglomerate also has characteristics of the traditional hierarchical scheme of unconformity belt, such as the disintegration zone, leaching zone, seepage layer and subsurface layer. Therefore, it is incorrect to classify it separately into a three layer structure. Under the mixed sand conglomerate is the normal sediment of underlying coarse gravel rock. The lithological difference between the upper and lower unconformity belt is obvious from the section graph of unconformity belt. The characteristics of the three-dimensional attribute of this kind of unconformity band can be clearly defined from the line structure graph and stereoscopic structure graph of the unconformity belt. It has a certain thickness, which is specifically embodied in the weathering, leaching, erosion and fracture degree between the upper and lower strata.

The profile in Figure 8B is from Liu Jiang basin, Qinhuangdao City, Hebei Province, China. A weathered clay layer is formed between the upper and lower carbonate rocks. Combined with the section graph, it is clearly difficult to carry on the structure stratification. Although different from the two-dimensional structure, i.e., the space has thickness, from the traditional three layer structure partition scheme, the whole unconformity belt structure is almost only one layer. However, it is exactly this layer that has the characteristics of weathering, erosion, leaching and rupture, which indicates the features of the three-dimensional structure. That is, as long as the space has a certain thickness but not necessarily the three layer structure, the structure can exist. For the formation of the process and the structure of the unconformity, the most critical factor is the integration of the time and the intensity of the erosion. The distribution of this kind of single layer structure in three-dimensional space can be defined based on the line structure and spatial structure. For the formation process of the unconformity structure, the most critical factor is the time and intensity of weathering and erosion or scouring of the unconformity belt. The distribution of this kind of single layer structure in three-dimensional space can be defined on the line structure graph and stereoscopic structure graph of unconformity belt.

The profile in Figure 8C is a section of Oregon, USA. The paleosol layer is formed between the upper and lower basalt lava, forming the three-dimensional structure of the unconformity belt. In this section, the layered structure of the upper and lower visual unconformity line is easily visible. Above the visual unconformity line, a layer of broken belt at the bottom of the overlying basalt lava can be seen, and pores and fractures are well developed. These impart different characteristics to the layer from the upper basalt lava, and should be divided into the structure of the unconformity belt, composing the upper unconformity boundary. Beneath the broken belt is a red paleosol layer. To distinguish this from the aforementioned clay layer, this is termed basalt clay rock, which constitutes the main structure of the unconformity belt. Below the basalt clay rocks is a gradual transition to the top of the underlying basaltic lava. In addition, this is also significantly different from the lower lava, subjected to severe weathering, erosion, leaching and rupture. Therefore, this part is also divided into the structure of the unconformity belt, composing the lower unconformity boundary. The characteristics can be seen from the line structure graph and stereoscopic structure graph of the unconformity belt, which seemingly appear to be divided into three layers, but there is also the unified whole that is subjected to weathering and leaching. The focus is still not the division of layers, but where it starts and where it ends. 
The profile in Figure 8D is based on Washington State, USA. The Pleistocene sandy conglomerate covers the underlying Miocene carbonate rocks, constituting the three-dimensional structure. The structure is similar to Figure 8C; the weathering and leaching strata around the upper and lower visual unconformity line constitutes the spatial attributes. The difference is that the main part of this profile is the carbonate rocks subjected to weathering and leaching of the lower unconformity boundary, and above the visual unconformity line a successively weathered clay layer and weathering and leaching of the sandy conglomerate occurs. Therefore, although it looks like the layered structure from the line structure graph and stereoscopic structure graph of the unconformity belt, there is still unity of weathering and leaching.

To sum up, combined with the model of three-dimensional structure, the following points are summarized:

1) From the perspective of formation mechanism, the underlying strata usually undergo weathering and denudation, representing a hiatus period. The underlying strata underwent weathering and leaching, and the formation of the overlying strata did not exert sufficient pressure on the weathered-fracture zone.

2) From the perspective of formation position, the three-dimensional structure is mainly formed under conditions of long-term exposure of the surface and weathering-leaching.

3) For the vertical characteristics of unconformity belt, there is a layered structure, but no absolute hierarchical structure. A weathered clay layer, basal conglomerate, water-inlet sandstone and so on can develop, and the weathering and leaching zone, dissolution-fracture zone and crush belt commonly develop, with an obvious spatial three-dimensional structure.

4) For the shape of unconformity belt, there are two clear visual unconformity lines that have no absolute relationship with unconformity boundary. The thickness between two visual unconformity lines is usually smaller than actual structure (Figure 4). Usually, the upper unconformity boundary is above the upper visual unconformity line, while the lower unconformity boundary is beneath the lower visual unconformity line.

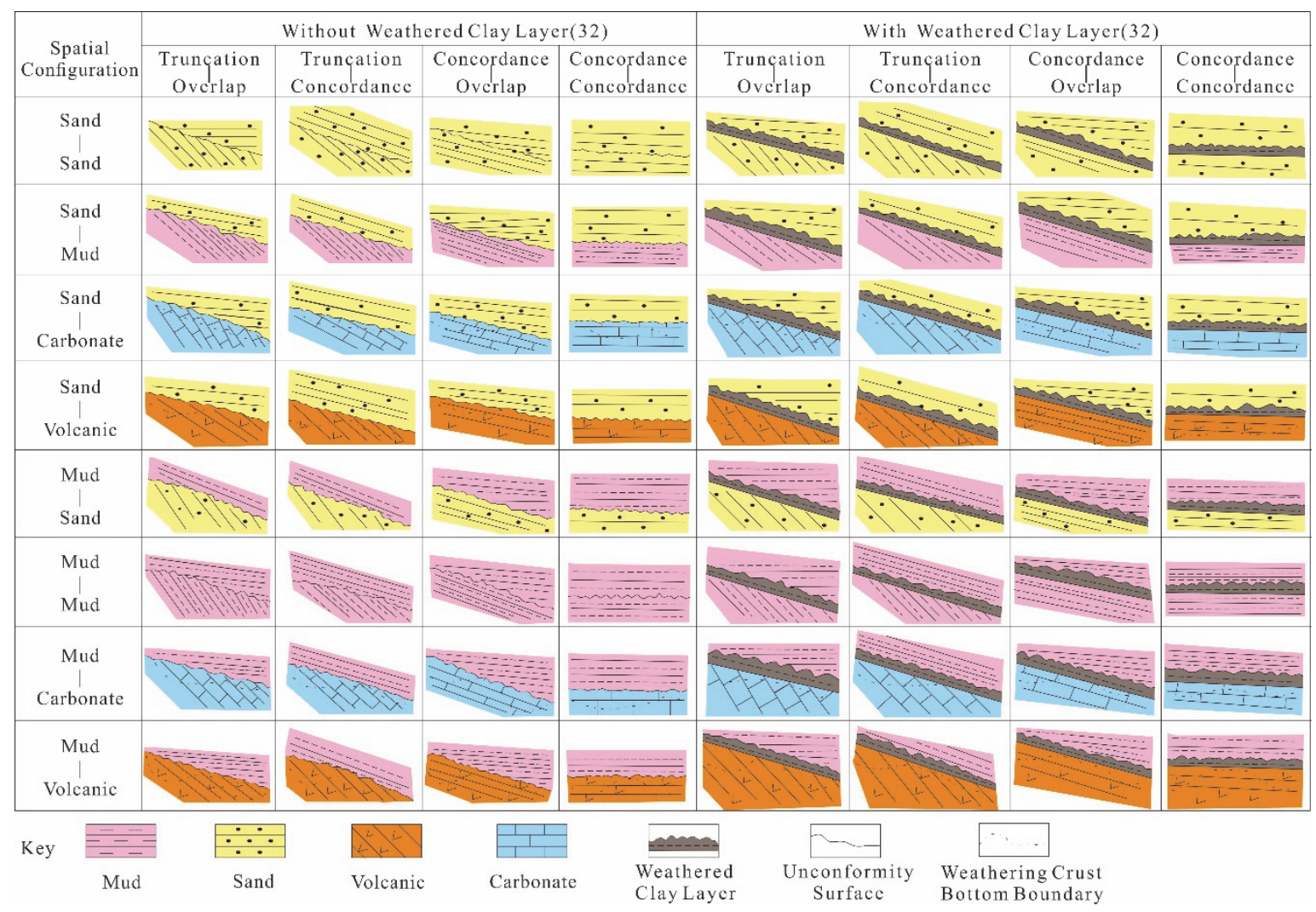

Figure 9. Spatial configuration of the unconformity structure type (modified from Dengfa $\mathrm{He}$ )

\section{Discussion}

Research on unconformity still has many points worth discussing, and study of unconformity belt with structure has important geological value for evolution of earth and tectonics, disaster events, oil and gas storage and 
transportation and so on. Here, the main point pertains to the discussion of micro spatial configuration and genetic mechanism of the unconformity.

\subsection{Micro Spatial Structure Configuration}

The structure of unconformity belt not only plays an important role in hydrocarbon migration and accumulation but also has considerable guiding significance for the study of history of geological development and identification of characteristics of crust movement (Morley, 2016). Both the two- and three-dimensional structure have important geological significance, which is reflected in the spatial structure configuration. With the function of sedimentary environment, climatic conditions, tectonic action, diagenesis, weathering and a variety of transformations, the structures originated through different methods of spatial structure configuration. Over the past 20 years, although there were few studies on the unconformity structure, no-one has meticulously depicted it or finely described the top and bottom surface. Most of the research focused on the level of contact relationships; the study of $\mathrm{He}$ (2007) discusses the spatial configuration by means of analysis for the unconformity type (Figure 9). In this way, however, the unconformity belt structure is confined to three layer structure, which cannot reflect the actual relationship of spatial configuration.

From the view of deposition process, the key factor is sedimentary environment. Moreover, an important reason for the formation of unconformity belt is that the changes in sedimentary environment bring about new sources, breaking the original sedimentary structures. Therefore, according to the leading role of the environment, considering the core elements - source supply, spatial configuration mode can be analyzed. In accordance with the difference in environment and source supply from 8 conditions: glacier migration, gravity sliding-collapse, volcanic activity, seismic activity, fluid erosion, tsunami activity, storm events and biochemistry actions, combined with the line structure graph and stereoscopic structure graph of unconformity belt, the spatial configuration can be divided into 16 kinds of combinations (Figure 10 and 11). It can be found that, in essence, the main influence on the structural characteristics is sedimentary environment and source supply of the upper unconformity belt, rather than the lower strata. For example, an unconformity belt formed from volcanic eruptions usually retains the marks of bullets and volcano ash, while that formed from seismic activity has characteristics of curls and deformation of upper seismite.

\subsection{Genetic Mechanism}

Traditional understanding is that due to the uplift of underlying strata, the ground is exposed to water and subject to weathering and denudation (Marsset et al., 2015; Xu, 2015). Through data and discussion of outcrops, numerous structures of unconformity belt, in particular, the two-dimensional structure, does not conform to this deposition process, such as unconformity belts that formed under water or inside the stratum. These unconformity belts belong to the event deposits. Some deposition processes are continuous while others are not. Therefore, it is obvious that exposure environment is not the determinant, and the three layer structures cannot meet the requirements of formation process. The actual phenomenon requires further understanding and research on genetic mechanism.

The same sedimentary environment and source supply can result in different unconformity belt structures, while different sedimentary environments and source supplies can lead to the same structures. It is thus evident that the formation of unconformity belt is controlled by multiple factors. When considering the genetic mechanism, it is noted that there are three key problems:

1) The evolution of the lower strata of the unconformity belt has no decisive influence on the formation, regardless of whether they fold due to tectonic movement; this is not the key for the formation of the unconformity belt, only an accompanying phenomenon.

2) The source supply of the upper layer of the unconformity belt has a decisive impact on the formation, i.e., determination of the two-dimensional structure or three-dimensional structure.

3) Exposure conditions are not the necessary elements for the formation of the unconformity belt, which can occur above and below water as well as inside the stratum. Further, the deposition process may be continuous.

Combining the extraction of outcrop data, based on the characteristics of the two- and three-dimensional structure and from the perspective of deposition process, conceptual models for genetic mechanism are proposed. 


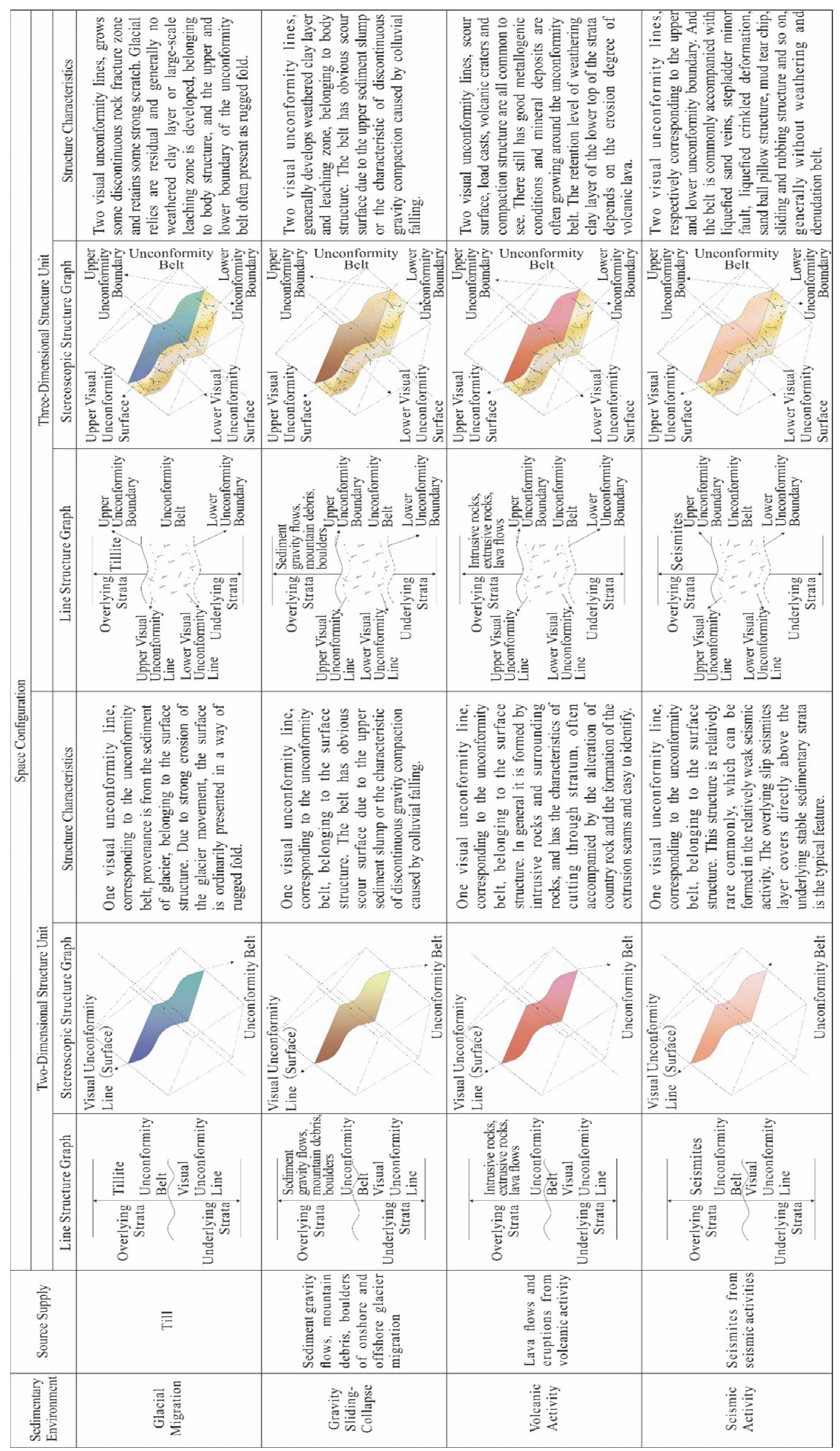

Figure 10. Spatial configuration of unconformity belt (Continued) 


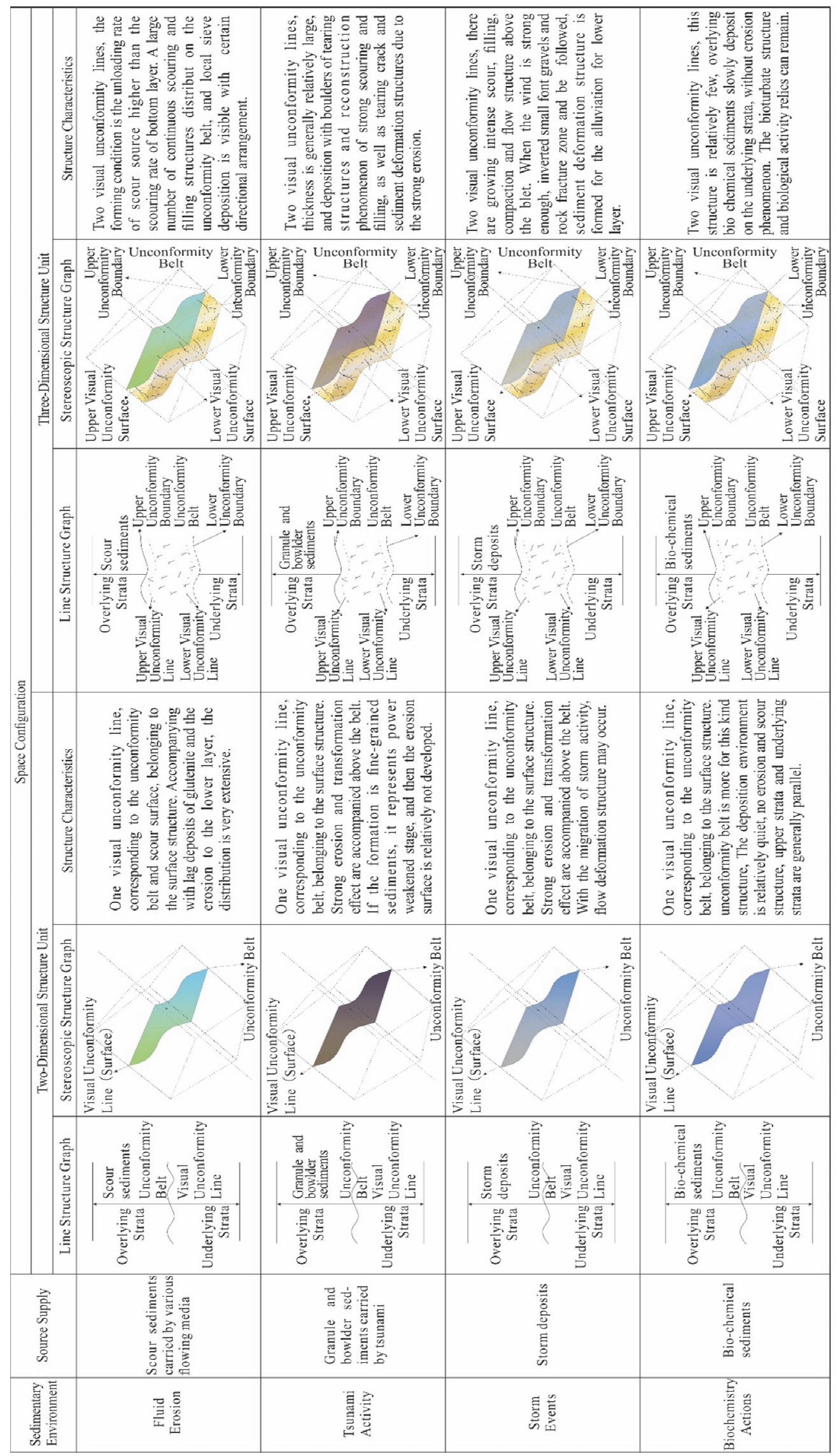

Figure 11. Spatial configuration of unconformity belt (Continued) 


\subsection{Genetic Model of Two-Dimensional Structure of Unconformity Belt}

There are four main types of genetic models for unconformity of the two-dimensional structure (Figure 12): unexposed deposition model, exposed-unweathered deposition model, invasion layer model and exposed-weathered strong erosion deposition model.

The unexposed deposition model (Figure 12A) consists of two stages. The first stage is before the formation of unconformity belt; the lower original formation remains in continuous deposition state, maintaining the layers for slow formation. The second stage is the formation stage. The original formation still remains in the continuous deposition state, without continuous transformation on the bedding caused by numerous organisms. Due solely to the geological environmental changes or tectonic movement, a new, foreign provenance supply originates, covering the original formation, but does not have continuous large-scale effects on the lower strata. It seems that the deposition of the lower strata is interrupted. In reality, the original deposition process is maintained continuously, but the rate of source supply does not become faster than the rate of foreign source supply. Between the upper and lower layers, the single visual unconformity lines occur, forming the two-dimensional structure of the unconformity belt.

The exposed-unweathered deposition model (Figure 12B) has three stages. The first stage is same as the last model. The second stage is exposure stage, due to geological environmental changes or tectonic movement, which causes basement to uplift or water to disappear. Thus, lower strata is exposed to ground and subjected to the effects of atmosphere, but not for long. The third stage is formation stage. Although lower strata is in an exposed condition, this is not sufficient for weathering and erosion transformation. Then, new source covers and forms the two-dimensional structure.

The invasion layer model (Figure 12C) has two stages. The first stage is same as the last model. In the second stage of invasion period, original formation still remains in a continuous deposition. As a result of volcanic activity, original formation is invaded by intrusive rocks. This invasion may not cause continuous cracking of surrounding rocks, forming the two-dimensional structure.

The exposed-weathered strong erosion deposition model (Figure 12D) consists of three stages. The first stage is same as the last model. The second stage is also the exposure stage because of the geological environmental changes or tectonic movement, and the basement uplifts or water disappears. Thus, the lower strata is exposed to the ground, resulting in weathering denudation and leaching phenomenon. Due to the difference in climatic conditions, exposed structures may appear, such as weathered clay, mud cracks and raindrop imprints, with longer duration. The third stage is the formation stage. The lower strata has sufficient time to undergo weathering and erosion transformation, forming the weathering zone. However, the new source has such strong erosion ability that it can wash away the weathering zone of lower strata, leaving only the erosion surface, thus forming the two-dimensional structure.

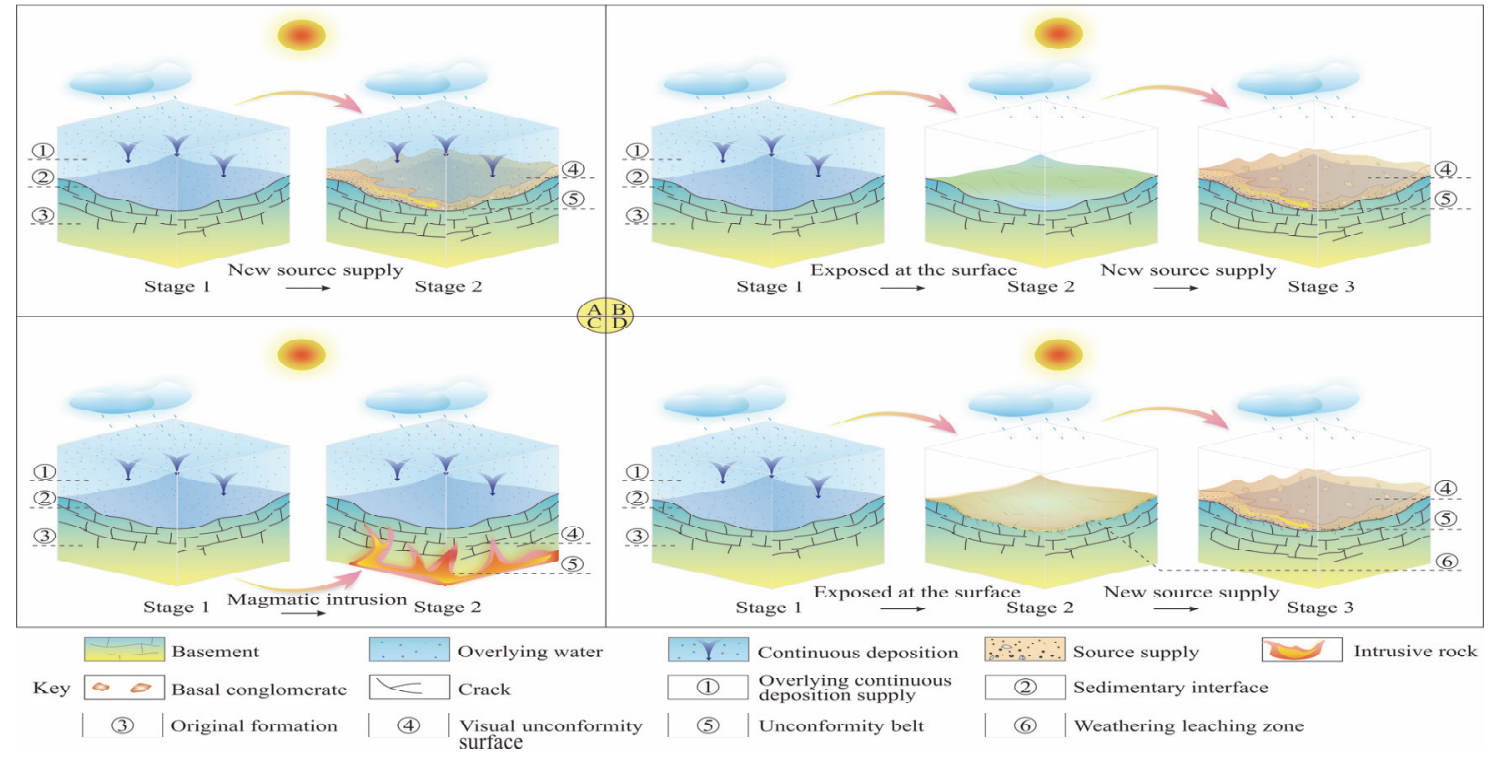

Figure 12. Genetic model of two-dimensional structure: A Unexposed deposition model; B

Exposed-unweathered deposition model; C Invasion layer model; D Exposed-weathered strong erosion deposition Model 


\subsection{Genetic Model of Three-Dimensional Structure of Unconformity Belt}

There are four main types of genetic models for unconformity of the three-dimensional structure (Figure 13): unexposed deposition model, exposed-unweathered deposition model, invasion layer model and exposed-weathered deposition model.

The unexposed deposition model (Figure 13A) has two stages. First stage occurs before the formation of unconformity belt; lower original formation remains in continuous deposition state, maintaining the layers for slow formation. The second stage is formation stage. The original formation still remains in a continuous deposition. A new exotic source supply is brought in caused by changes of geological environment and tectonic movement, covering the original formation. However, with the provenance supply, lower strata undergos continuous changes. There may be considerable migration and escape marks of many organisms, and continuous rupture and compaction caused by strong erosion of new source may occur in lower strata. There is no single visual unconformity line; instead, two occur and form the three-dimensional structure.

The exposed-unweathered deposition model (Figure 13B) has three stages. The first stage is same as the last model. Second stage is exposure process, due to geological environmental changes and tectonic movement, the basement is caused to uplift and water disappears. Lower strata is exposed, but transformation phenomenon has not yet occurred and when does so, occurs with shorter duration. In the third stage, new source directly covers over lower stratum. With a continuous transformation function, the lower strata appears to forming a continuous scouring fracture and deformation structure, imparting a certain thickness to unconformity belt. The two visual unconformity lines emerge and forms the three-dimensional structure.

The invasion layer model (Figure 13C) has two stages. First stage is same as the last model. The second is invasion period; original formation still remains under continuous deposition. As a result of volcanic activity, original formation is invaded by intrusive rocks. This invasion causes continuous cracking and alteration on surrounding rocks, even forms a metallogenic belt, imparting a certain thickness to the unconformity belt, resulting in the appearance of two visual unconformity lines and forming the three-dimensional structure.

The exposed-weathered deposition model (Figure 13D) consists of three stages. The first stage is same as the last model. The second stage is also exposure stage, and because of geological environmental changes and tectonic movement, the basement uplifts or water disappears. Thus, lower strata is exposed to ground, resulting in weathering denudation and leaching phenomenon. Due to the difference in climatic conditions, it is possible that exposed structures such as weathered clay, mud cracks and raindrop imprints may occur with longer duration. The third stage is formation stage. New source supply covers over lower strata and does not exert continuous damage on the transformation of understratum. Thus, a certain thickness forms, resulting in the appearance of two visual unconformity lines and formation of the three-dimensional structure.

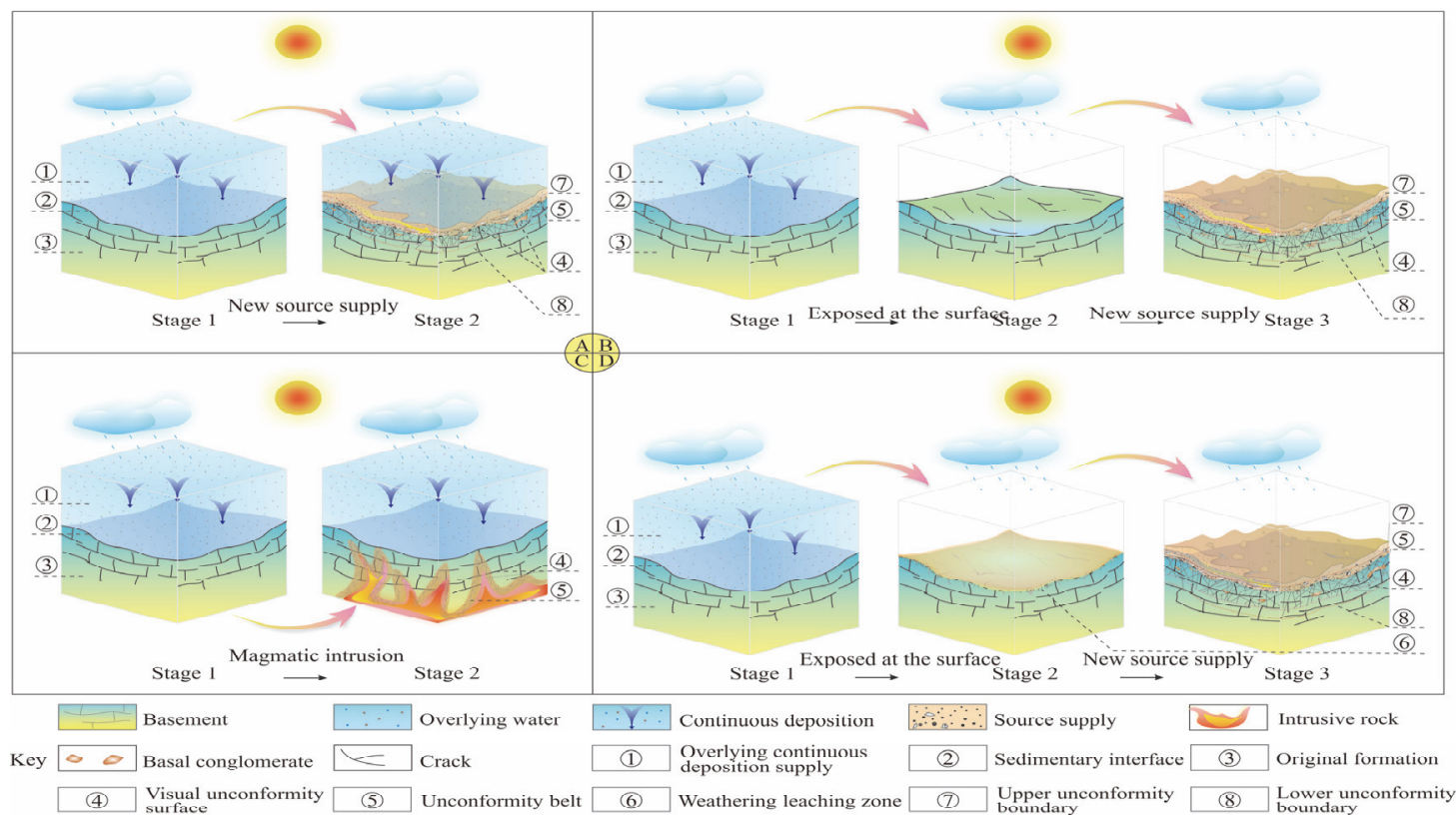

Figure 13. Genetic model of three-dimensional structure: A Unexposed deposition model; B

Exposed-unweathered deposition model; C Invasion layer model; D Exposed-weathered deposition Model 


\section{Conclusions}

The structure of unconformity belt is not a single two-dimensional surface or general absolute three-layer structure, but a combination of the two according to the difference in sedimentary environment and provenance supply. Different unconformity belt structures have different characteristics; these can reflect the formation mechanism and process. Combined with the idea of depositional process and discussion of this paper, five points following are reached:

1) The depiction of unconformity needs to account for these important structural elements: visual unconformity line, visual unconformity surface, upper unconformity boundary, lower unconformity boundary, vertical thickness, transverse distribution, rock types, contact relationship, forming environment and so on. Among them, the visual unconformity line is the most direct factor for field identification. The structure of unconformity belt can comprise one or two visual unconformity lines.

2) The two-dimensional structure of unconformity belt has a single visual unconformity line and general corresponds to the belt itself, representing a single two-dimensional surface. The lower strata do not undergo weathering and denudation but can develop a scouring structure. It often forms inside the stratum or on the contact surface of the flowing medium, with close contact between the upper and lower strata. It usually forms in the sedimentary environment with considerable burst source supply, such as glacial migration, gravity sliding-collapse, intrusive activities, fluid erosion and biological chemistry actions.

3) The three-dimensional structure of unconformity belt has two visual unconformity lines usually between the upper and lower unconformity boundary. These can coincide with each other under appropriate situation, representing spatial structure with a certain thickness, but not the absolute three-layer structure. The bottom gravel layer, weathered clay layer and leaching crushing zone usually have no absolute boundaries, they are continuous and form the three-dimensional structure itself. Due to the erosion and weathering of overlying source washing, unconformity belt often forms various erosion filling, fracture zone, sediment deformation, tearing and leaching structures. It is also a good position for a metallogenic belt, which usually develops under the condition that lower strata undergos surface weathering and denudation of the ground with a considerable source supply, such as volcanic activity, seismic activity, tsunami activity, and storm events.

4) Combined with the developmental model of two- and three-dimensional structure and field outcrop, and based on the factors of the sedimentary environment and provenance supply, 16 kinds of micro spatial configurations are presented; characteristics of various structures are given combined with the actual data.

(5) Combined with the developmental characteristics of the two- three-dimensional structure, the formation mechanisms are discussed, and on the basis of actual data, a genetic model of two-dimensional structure and three-dimensional structure is proposed.

\section{Acknowledgments}

The project received co-financial support from the National Natural Sciences Fund "Research on Spatiotemporal Variations Mechanism of Lateral Accretion within Point Bar Based on Conditions of Physical Simulation" (41372125), Fund of Ministry of Education of Hubei Province "Research on Flow Units Controlling Remaining Oil Based on Conditions of Reservoir Architecture "(Q20121210), and the Ministry of Education key Laboratory on Tectonics and Petroleum Resources in China University of Geosciences (Wuhan) open foundation "Research on Reservoir Architecture Controlling Remaining Oil in the Meandering Channel Sandbody" (TPR-2012-23)

\section{References}

Ai, H., Lan, L., Zhang, K., \& Wu, Y. (1996). The characteristics of the unconformity on the top of Precarboniferous and its constraints on oil/gas behavionr in Tarim Basin. Petroleum Geology and Experiment, 18(1), 1-13.

Befus, A. D. (1994). Unconformities and porosity development in carbonate strata: ideas from a Hedberg conference. AAPG Bulletin, 78(6), 857-872. http://doi.org/10.2307/3282019

Billings, M. P. (1961). Structural Geology. Prentice-Hall, C.E. Tuttle.

Blackwelder, E. (1909). The valuation of unconformities. Journal of Geology, 17(3), $289-299$.

Brown, L. F., \& Fisher, W. L. (1982). Seismic stratigraphic interpretation and petroleum exploration. The American Association of Petroleum Geologists, 17(6), 1030-1035.

Burchette, T. P. (1996). Unconformities and porosity in carbonate strata. Marine \& Petroleum Geology, 13(5), 
596-597. http://doi.org/10.1016/0264-8172(96)88336-X

Chang, B. (2006). Relationship between unconformity system and heterogeneous migration of petroleum in continental basins. Acta Petrolei Sinica, 27(5), 19-23. http://doi.org/10.7623/syxb200605003

Chow, N., \& Wendte, J. (2011). Palaeosols and palaeokarst beneath subaerial unconformities in an Upper Devonian isolated reef complex (Judy Creek), Swan Hills Formation, west-central Alberta, Canada. Sedimentology. 58, 960-993. http://doi.org/10.1111/j.1365-3091.2010.01191.x

Clari, P. A., Dela, P. F., \& Martire, P. L. (1995). Discontinuities in carbonate successions: identification, interpretation and classification of some Italian examples. Sedimentary Geology. 100, 97-121. http://doi.org/10.1016/0037-0738(95)00113-1

Farouk, S., \& El-Sorogy, A. (2015). Danian/ Selandian unconformity in the central and southern Western Desert of Egypt. Journal of African Earth Sciences, 103, 42-53. http://doi.org/10.1016/j.jafrearsci. 2014.12.002

Friedman, G. M., Sanders, J. E., \& Kopaska-Merkel, D. C. (1992). Principles of sedimentary deposits. Macmillan Publishing Company, New York.

Fu, G., Duan, H., \& Meng, Q. (2005). Unconformity and transport hydrocarbon characteristic. Petroleum Geology \& Oilfield Development in Daqing, 36(4), 518-524. http://doi.org/10.3969/j.issn.1000-3754.2005.01.004

Fu, G., Xu, Z., Han, D., \& Ji, Z. (2001). Role of surface of unconformity in formation of oil or gas reservoirs. Journal of Daqing Petroleum Institute, 25(1), 1-4. http://doi.org/10.3969/j.issn.2095-4107.2001.01.001

Gao, C., Peng, P., \& Li, B. (2013). Unconformity types and their constraints on hydrocarbon behavior. Lithologic Reservoirs, 25(6), 1-7. http://doi.org/10.3969/j.issn.1673-8926.2013.06.001

Gao, Z., \& Fan, T. (2015). Unconformities and their influence on lower paleozoic petroleum reservoir development in the Tarim Basin. Journal of Petroleum Science and Engineering, 133, 335-351. http://doi.org/10.1016/j.petrol.2015.06.015

Guo, W., Mou, Z., Zhao, W., \& Deng, G. (2006). Research on the relation of unconformity type with oil and gas migration-accumulation at Zhuengaer Basin. Journal of Southwest Petroleum Institute, 28(2), 1-3. http://doi.org/10.3863/j.issn.1674-5086.2006.02.001

He, D. (2007). Structure of unconformity and its control on hydrocarbon accumulation. Petroleum Exploration and Development, 34(2), 142-150. http://doi.org/10.3321/j.issn:1000-0747.2007.02.003

Li, H., \& Ai, H. (2006). The reservoirs and seals below and above the unconformity surfaces- the key factor for hydrocarbon accumulation in the Tarim Basin. West China Petroleum Geosciences, 2(4), 390-396.

Lu, K. (1980). On classification of unconformities and their distribution in oil-bearing basin. Journal of China University of Petroleum (Edition of Natural Science), (3), 10-19.

Marsset, T., Bayon, G., Cathalot, C., Caprais, J. C., Bermell, S., Sotin, C., ... Berrenstein, H. (2015). Origin of an enigmatic regional Mio-Pliocene unconformity on the Demerara plateau. Marine Geology, 365, 21-35. http://doi.org/10.1016/j.margeo.2015.04.001

Miall, A. D. (2016). The valuation of unconformities. Earth-Science Reviews, 163, 22-71. http://doi.org/10.101 6/j.earscirev. 2016.09.011

Miall, A. D. (1984). Principles of sedimentary basin analysis. Springer-Verlag, NewYork.

Mitchum, R. M. (1977). Seismic stratigraphy and global changes of sea level, Part 1: Glossary of terms used in seismic straitgraphy. In: C.E. Payton (Ed.), Seismic Stratigraphy-Applications to Hydrocarbon Exploration (pp. 205-212). American Association Petroleum Geologists Memoir.

Morley, C. K. (2016). Major unconformities/termination of extension events and associated surfaces in the South Shina Seas: Review and implications for tectonic development. Journal of Asian Earth Sciences, 120, 62-86. http://doi.org/10.1016/j.jseaes.2016.01.013

Nieto, L. M., Rodriguez-Tovar, F. J., Molina, J. M., Reolid, M., \& Ruiz-Ortiz, P. A. (2014). Unconformity surfaces in pelagic carbonate environments: a case from the Middle Bathonian of the Betic Cordillera, SE Spain. Geology, 84(3), 281-295.

Pinet, N., Lavoie, D., Dietrich, J., Hu, K., \& Keating, P. (2013). Architecture and subsidence history of the intracratonic Hudson Bay Basin, Northern Canada. Earth-Science Reviews, 125(3), 1-23. http://doi.org/10.1016/j.earscirev.2013.05.010 
Qiu, Y., Cheng, R., \& Lin, C. (2002). Unconformity types of the lower tertiary and their geological significance in zhanhua trough. Journal of Jilin University (Earth Science Edition), 32(2), 146-150. http://doi.org/10.13278/j.cnki.jjuese.2002.02.008

Qu, J., Gao, C., \& Zha, M. (2013). Structure of the cenozoic bottom unconformity zone in Ji Zhong depression and its significance on hydrocarbon accumulation. Petroleum geology and engineering, 27(3), 1-4. http://doi.org/10.3969/j.issn.1673-8217.2013.03.001

Qu, Y., Pan, J., Ma, S., Lei, Z., Li, L., \& Wu, G. (2014). Geological characteristics and tectonic significance of unconformities in Mesoproterozoic successions in the northern margin of the North China Block. Geoscience Frontiers, 5, 127-138. http://doi.org/10.1016/j.gsf.2013.04.002

Ryu, I. C., Chang, W. O., \& Kim, S. W. (2005). A Middle Ordovician drowning unconformity on the northeastern flank of the Okcheon (Ogcheon) belt, South Korea. Gondwana Research, 8(4), 511-528. http://doi.org/10.1016/S1342-937X(05)71152-7

Sattler, U., Immenhauser, A., Hillgartner, H., \& Esteban, M. (2005). Characterization, lateral variability and lateral extent of discontinuity surfaces on a carbonate platform (Barremianto Lower Aptian, Oman). Sedimentology, 52(2), 339-361. http://doi.org/10.1111/j.1365-3091.2005.00701.x

Sloss, L. L. (1988). Tectonic evolution of the craton in Phanerozoic time. In: L. L. Sloss (Ed.), Sedimentary Cover-North American Craton, US (pp. 25-51). Geological Society of America, The Geology of North America.

Vail, P. R., Mitchum, R. M., \& Thompson III, S. (1977). Seismic stratigraphy and global changes of sea level, part 3: relative changes of sea level from coastal onlap. Antimicrobial Agents \& Chemotherapy, 41(9), $1859-1866$.

Wang, Y., Cao, Y., Wang, S., \& Song, Y. (2006). Advances in research of spatial structures of unconformity. Geotectonica et Metallogenia, 30(3), 326-330. http://doi.org/10.3969/j.issn.1001-1552.2006.03.008

Winter, H. R., \& Brink, M. C. (1991). Chronostratigraphicsubdivision of the Witwatersrand Basin based on a Western Transvaal composite column. South African Journal of Geology, 94, 191-203.

Wu, K., Li, L., \& Zha, M. (2009). Vertical structures of unconformity and its simulation experiment of hydrocarbon accumulation mechanism. Petroleum Geology \& Experiment, 31(5), 537-542. http://doi.org/10.11781/sysydz200905537

Wu, K., Zha, M., \& Hong, M. (2003). Structural models of unconformity and recurrent diagenesis of semi-weathering rock in Junggar Basin. Geotectonica et Metallogenia, 27(3), 270-276. http://doi.org/1 0.3969/j.issn.1001-1552.2003.03.009

Wu, K., Zou, C., Zha, M., \& Gao, C. (2012). Controls of unconformity on the formation of stratigraphic $\begin{array}{llll}\text { reservoirs. } \quad \text { Geotectonica } & \text { Metallogenia, } & 36(4), & \text { 518-524. }\end{array}$ http://doi.org/10.3969/j.issn.1001-1552.2012.04.005

Wu, Y., Zhang, S., \& Ai, H. (1998). The unconformity types and their relations with oil/gas reservoirs in tarim basin. Xinjiang Petroleum Geology, 19(2), 9-13. http://doi.org/10.3969/j.issn.1673-8217. 2013.03.001

$\mathrm{Xu}$, Y. (2015). Characteristics and reservoir-forming action of Guojingzi Qianshan Zone unconformity in Bamianhe area. Journal of Jianghan Petroleum University of Staff and Workers, 28(6), 9-12. http://doi.org/10.3969/j.issn.1009-301X.2015.06.003

Yang, Y. (2006). The study on the development characteristic of unconformity and its effect on the migration and accumulation of hydrocarbon. China University of Petroleum, Wuhan, China.

Yin, Z. X. (1978). Problems existing in stratigraphic code. Journal of Stratigraphy, 2(1), 1-6.

Zecchin, M., Praeg, D., Ceramicola, S., \& Muto, F. (2015). Onshore to offshore correlation of regional unconformities in the Plio-Pleistocene sedimentary successions of the Calabrian Arc (central Mediterranean). Earth-Science Reviews, 142, 60-78. http://doi.org/10.1016/j.earscirev.2015.01.006

Zhang, K., Ai, H., \& Wu, Y. (1996). Characteristics and oil-controlling significance of unconformity structure layer on top of carbonate rock. Petroleum Exploration and Development, 23(5), 16-19.

Zhou, Y., Lu, Y., Li, S., \& Wang, H. (1997). The missing time calculation of the hiatus surface - a case stude of the upper Permian reefs section at the platform margin, Ziyun, Guizhou. Acta Geologica Sinica, 71(1), 7217. 
Ziegler, K. (2000). Multiple episodes of clay alteration at the Precambrian/Paleozoic unconformity, Appalachian Basin: isotopic evidence for long-distance and local fluid migrations. Clays \& Clay Minerals, 48(4), 474-493. http://doi.org/10.1346/CCMN.2000.0480407

\section{Copyrights}

Copyright for this article is retained by the author(s), with first publication rights granted to the journal.

This is an open-access article distributed under the terms and conditions of the Creative Commons Attribution license (http://creativecommons.org/licenses/by/4.0/). 